MENYOAL PROFESIONALISME GURU PROFESIONAL: SEBUAH TELAAH KRITIS

\author{
Amru Almu'tasim \\ STIT Uluwiyah Mojokerto \\ e-mail:amru.dosen@yahoo.com
}

\begin{abstract}
Teacher is a designation for the position, position and profession for someone who devoted himself in the field of education through educational interaction patterned, formal, and systematic (Surya, 1998). Historically professorship connote uplifted services (noblest vocation). They named the child paedagogos or waiters, waitresses humanizing honorable man, or man of human beings (gogos humanities). Guru is one of the human component in the teaching-learning process, which had a role in the formation of human resources business potential in development. Therefore, teachers must be someone who can 'digugu' and 'imitated'. Teachers must participate actively and putting his position as professionals, in accordance with the demands of the growing community.
\end{abstract}

Keywords: professionalism, professional teacher

\begin{abstract}
Abstrak: 'Guru' adalah suatu sebutan bagi jabatan, posisi dan profesi bagi seseorang yang mengabdikan dirinya dalam bidang pendidikan melalui interaksi edukatif secara terpola, formal, dan sistematis (Surya, 1998). Secara historis jabatan guru mengandung arti pelayanan yang luhur (noblest vocation). Mereka disebut dengan paedagogos atau pelayan anak, pelayan terhormat yang memanusiakan manusia, atau abdi manusia (gogos humaniora). Guru adalah salah satu komponen manusiawi dalam proses belajar-mengajar, yang ikut berperan dalam usaha pembentukan sumber daya manusia yang potensial dalam pembangunan. Oleh karena itu, guru haruslah sosok yang dapat 'digugu' dan 'ditiru'. Guru harus berperan serta aktif dan menempatkan kedudukannya sebagai tenaga profesional, sesuai dengan tuntutan masyarakat yang semakin berkembang.
\end{abstract}

Kata-Kata Kunci: Profesionalisme, Guru Profesional

\title{
Pendahuluan
}

Profesi pada hakikatnya adalah suatu pernyataan atau suatu janji terbuka (to profess artinya menyatakan), yang menyatakan bahwa 
seseorang itu mengabdikan dirinya pada suatu jabatan atau pelayanan karena orang tersebut merasa terpanggil untuk menjabat pekerjaan itu. Profesi ialah sebutan kepada suatu jabatan atau pekerjaan yang membutuhkan keahlian atau persyaratan khusus tertentu (Surya, 1998). Hal ini mengandung arti bahwa suatu jabatan atau pekerjaan yang disebut profesi tidak dapat dipegang oleh sembarang orang, akan tetapi memerlukan suatu persiapan melalui pendidikan dan pelatihan yang dikembangkan khusus untuk itu.

Mengenai istilah profesi ini Everett Hughes menjelaskan bahwa istilah profesi merupakan simbol dari suatu pekerjaan dan selanjutnya menjadi pekerjaan itu sendiri. (Chandler, 1960). Sedangkan istilah 'profesionalisasi' dapat diartikan sebagai suatu proses menuju kepada perwujudan dan peningkatan profesi dalam mencapai suatu kriteria yang sesuai dengan standar yang telah dipersiapkan (Surya, 1998). Dengan profesionalisasi, maka guru secara bertahap diharapkan akan mencapai suatu derajat kriteria profesional sesuai dengan standar yang telah ditetapkan.

\section{Makna Guru Sebagai Profesi}

'Guru' adalah suatu sebutan bagi jabatan, posisi dan profesi bagi seseorang yang mengabdikan dirinya dalam bidang pendidikan melalui interaksi edukatif secara terpola, formal, dan sistematis (Surya, 1998). Menurut UU RI No. 14 Tahun 2005 (Undang-Undang Tentang Guru dan Dosen) guru adalah pendidik profesional dengan tugas utama mendidik, membimbing, mengarahkan, melatih, menilai, an mengevaluasi peserta didik pada pendidikan anak usia dini jalur pendidikan formal, pendidikan dasar, dan pendidikan menengah. (Suparlan, 2006).

B.J Chandler menegaskan bahwa profesi mengajar adalah suatu jabatan yang mempunyai kekhususan. Kekhususan itu memerlukan kelengkapan mengajar dan/atau keterampilan yang menggambarkan bahwa seorang melakukan tugas mengajar, yaitu membimbing manusia. Guru profesional akan tercermin dalam penampilan pelaksanaan pengabdian tugasnya yang ditandai dengan keahlian, rasa tanggung jawab, dan rasa kesejawatan dengan temannya. Guru mempunyai peranan (role) yang luas baik di sekolah, di dalam 
keluarga, maupun di masyarakat. Di sekolah ia berperan sebagai perancang dan pengelola pembelajaran, penilai hasil pembelajaran siswa, pengarah pembelajaran, dan sebagai pembimbing siswa. Di dalam keluarga guru berperan sebagai pendidik keluarga (family educator). Sedangkan di masyarakat guru berperan sebagai pembina masyarakat (social developer), pendiorong masyarakat (social motivator), pembaharu masyarakat (social innovator), dan sebagai agen masyarakat (social agent). Guru yang profesional ialah guru yang dapat memainkan semua peranan itu secara baik dan benar.

\section{Ciri-Ciri Guru sebagai Profesi}

Chandler menjelaskan ciri suatu profesi yang dikutip dari suatu publikasi yang dikeluarkan oleh British Institute of Management. Di situ Chandler mencoba mengemukakan dan menerapkan ciri-ciri profesi itu dalam bidang pendidikan bagi para guru sebagai berikut:

a. Mengutamakan layanan sosial, lebih dari kepentingan pribadi.

b. Mempunyai status yang tinggi.

c. Memiliki pengetahuan yang khusus (dalam hal mengajar dan mendidik).

d. Memiliki kegiatan intelektual.

e. Memiliki hak untuk memperoleh standard kualifikasi professional.

f. Mempunyai kode etik profesi yang ditentukan oleh organisasi profesi.

Selanjutnya Westby dan Gibson mengemukakan ciri-ciri keprofesian di bidang pendidikan sebagai berikut :

a. Diakui oleh masyarakat dan layanan yang diberikan hanya dikerjakan oleh pekerja yang dikategorikan sebagai suatu profesi.

b. Memiliki sekumpulan bidang ilmu pengetahuan sebagai landasan dari sejumlah teknik dan prosedur yang unik.

c. Diperlukan persiapan yang sengaja dan sistematis sebelum orang itu dapat melaksanakan pekerjaan profesional.

d. Memiliki mekanisme untuk menyaring sehingga orang yang berkompeten saja yang diperbolehkan bekerja. 
e. Memiliki organisasi profesional untuk meningkatkan layanan pada masyarakat.

Selain beberapa ciri di atas Pidarta (1997) menambahkan bahwa ciri profesi, yakni:

a. Pilihan terhadap jabatan itu didasari oleh motivasi yang kuat dan merupakan panggilan hidup guru bersangkutan.

b. Mempunyai otonomi dalam bertindak ketika melayani klien.

c. Tidak mengadvertensikan keahliannya untuk mendapatkan klien.

Bila diperhatikan ciri-ciri profesi tersebut di atas tampak bawa profesi pendidik tidak mungkin dapat dikenakan kepada sembarang orang yang dipandang oleh masyarakat umum sebagai pendidik.

Mendidik adalah membuatkan kesempatan dan menciptakan situasi yang kondusif agar anak-anak sebagai subjek berkembang sendiri. Mendidik adalah suatu upaya membuat anak-anak mau dan dapat belajar atas dorongan diri sendiri untuk mengembangkan bakat, pribadi, dan potensi-potensi lainnya secara optimal. Berarti mendidik memusatkan diri pada upaya pengembangan afeksi anak-anak, sesudah itu barulah pada pengembangan kognisi dan keterampilannya. Pengembangan afeksi yang positif terhadap belajar, merupakan kunci keberhasilan belajar berikutnya, termasuk keberhasilan dalam meraih prestasi kognisi dan keterampilan. Bila afeksi anak sudah berkembang secara positif terhadap belajar, maka guru, dosen, orang tua, maupun anggota masyarakat tidak perlu bersusah payah membina mereka agar rajin belajar. Apapun yang terjadi mereka akan belajar terus untuk mencapai cita-cita.

Inilah pengertian yang benar tentang mendidik. Melakukan pekerjaan mendidik seperti ini tidaklah gampang. Hanya orang-orang yang sudah belajar banyak tentang pendidikan dan sudah terlatih yang mampu melaksanakannya. Ini berarti pekerjaan mendidik memang harus profesional. Profesionalisasi seperti ini di bidang pendidikan memang harus dilakukan bila ingin pendidikan berhasil. 


\section{Guru yang Profesional}

Sebelum kita membahas seorang guru itu dikatakan profesional atau tidak maka kita harus memahami apa makna sebenarnya dari kata profesional itu sendiri, pada umumnya orang memberi arti sempit pada pengertian profesional. Profesional sering diartikan sebagai suatu keterampilan teknis yang dimilki seseorang, misalnya seorang guru, dia baru dikatakan profesional bila guru itu memiliki kualitas mengajar yang tinggi. Padahal profesional itu mempunyai makna yang lebih luas dari sekedar berkualitas tinggi dalam hal teknis. Surya (1998) berpendapat bahwa profesional mempunyai makna yang mengacu kepada sebutan tentang orang yang menyandang suatu profesi dan sebutan tentang penampilan seseorang dalam mewujudkan unjuk kerja sesuai dengan profesinya. Penyandangan dan penampilan 'profesional' ini telahmendapat pengakuan baik secara formal maupun informal. Sedang dalam Undang-Undang guru dan dan dosen yang sampai saat ini masih terus menjalani proses perbaikan yang diperlukan, di situ disebutkan bahwa profesional adalah pekerjaan atau kegiatan yang dilakukan oleh seseorang dan menjadi sumber penghasilan kehidupan yang memerlukan keahlian, kemahiran, atau kecakapan yang memenuhi standar mutu atau norma tertentu serta memerlukan pendidikan profesi.

Guru profesional akan tercermin dalam penampilan pelaksanaan pengabdian tugasnya yang ditandai tiga dimensi, yaitu :

1. Expert

2. Rasa tanggungjawab

3. Rasa kesejawatan

\section{Ahli (Expert)}

Guru profesional adalah guru yang memiliki keahlian baik dalam materi maupun metode. Keahlian yang dimiliki guru profesional adalah keahlian yag diperoleh melalui suatu proses pendidikan dan latihan yang diprogramkan khusus untuk itu. Keahlian tersebut mendapatkan pengakuan formal yang dinyatakan dalam bentuk sertifikasi, akreditasi, dan lisensi dari pihak yang berwenang (dalam hal ini pemerintah dan organisasi profesi). Dengan keahliannya itu seorang 
guru mampu menunjukkan otonominya baik sebagai pribadi ataupun sebagai pemangku profesi.

\section{Memiliki Rasa Tanggungjawab}

Guru profesional harus menguasai apa yang disajikan dan bertanggungjawab (accountability) atas semua yang diajarkan. Ia bertanggungjawab atas segala tingkah lakunya. Pengertian bertanggungjawab menurut teori ilmu mendidik mengandung arti bahwa seseorang mampu memberi pertanggungjawaban dan kesediaan untuk dimintai pertanggungjawaban. Tanggung jawab yang mempunyai makna multidimensional ini berarti bertanggung jawab terhadap diri sendiri, terhadap siswa, terhadap orang tua, lingkungan sekitarnya, masyarakat, bangsa, negara, sesama manusia, agama, dan yang akhirnya bertanggungjawab terhadap Tuhan Yang Maha Esa. Tangung jawab pribadi tercermin dari kemampuan mewujudkan dirinya sebagai pribadi yang mandiri dan menghargai serta mengembangkan dirinya. Tangungjawab sosial diwujudkan melalui kompetensi guru dalam memahami dirinya sebagai bagian yang tak terpisahkan dari lingkungan sosial, serta memiliki kemampuan interaktif yang efektif. Tanggung jawab spiritual dan moral diwujudkan melalui penampilan guru sebagai makhluk yan beragama, yang perilakunya senantiasa tidak menyimpang dari norma agama dan moral.

\section{Memiliki Rasa Kesejawatan}

Rasa kesejawatan adalah satu perwujudan solidaritas kebersamaan sesama guru sebagai sumber dinamika kebersamaan dalam mencapai tujuan bersama. Salah satu tugas dari organisasi profesi ini (baca: PGRI) ialah menciptakan rasa kesejawatan sehingga ada rasa aman dan perlindungan jabatan. PGRI mempunyai fungsi sebagai wadah kebersamaan rasa kesejawatan para anggota dalam:

1) Mewujudkan keberadaannya di lingkungan masyarakat

2) Memperjuangkan segala aspirasi dan kepentingannya suatu profesi

3) Menetapkan standar perilaku profesional

4) Melindungi seluruh anggota 
5) Meningkatkan kualitas kesejahteraan

6) Mengembangkan kualitas pribadi dan profesi

Dengan adanya organisasi profesi, setiap anggota mendapat perlindungan dalam mewujudkan profesionalitasnya secara lebih terarah dan efektif dalam suasana rasa aman yang kondusif. PGRI merupakan wadah perjuangan hak-hak azasi guru sebagai pekerja. PGRI berfungsi untuk melakukan berbagai upaya dalam mewujudkan hak asasi guru sebagai pekerja, terutama dalam kaitan dengan kesejahteraan. Guru sebagai kelompok tenaga kerja profesional memerlukan jaminan yang pasti baik yang menyangkut hukum, kesejahteraan, hak-hak pribadi dan warga negara dalam mewujudkan kinerjanya. Dalam konsep yang lebih luas, kesejahteraan mempunyai makna sebagai suatu kondisi kehidupan yang utuh, seimbang, dan wajar. Perwujudan kesejahteraan secara utuh ditopang oleh lima pilar yaitu: (1) imbalan jasa, (3) rasa aman, (3) hubungan antar pribadi, (4) kondisi kerja, dan (5) kesempatan untuk pengembangan dan peningkatan karir dan pribadi.

Semangat kesejawatan perlu dikembangkan agar harkat dan martabat guru dijunjung tinggi baik oleh korps guru sendiri maupun masyarakat pada umumnya. Selain itu supaya penghargaan dan perlindungan terhadap jabatan guru sesuai dengan tanggungjawab yang dilimpahkan pada mereka.

\section{Paradigma Kategori Guru Profesional}

Paradigma memiliki dua makna, yaitu: pertama pertanyaan yang terus menerus dipertanyakan atau pertanyaan yang selalu berulang. Kedua paradigma merupakan suatu model analisis. Guru dalam konteks pemahaman tentang hakekat manusia yaitu manusia sebagai ciptaan tuhan punya kemungkinan untuk berkembang, serta manusia memiliki identitas seperti identitas individual, moral dan sosial

Untuk menjadi guru yang profesional tidak hanya memerlukan pengetahuan dan pengalaman saja, sebab seorang guru juga dituntut untuk mengenali diri sendiri sebagai salah satu bekal untuk menuju tingkat keprofesionalannya. Seorang guru yang profesional seyogyanya 
mampu mengambil keputusan serta membuat rencana yang disesuaikan dengan kondisi siswa, situasi, wawasannya sendiri, nilai, serta komitmennya (Zumwalt, 1989) Ia harus mampu membaca situasi (seperti karakteristik siswa, ruang, waktu, sarana/fasilitas, perkembangan dalam dunia pembelajaran) dan kemudian menyesuaikan rencananya dengan situasi yang akan dihadapi. Pada bagian ini akan dijelaskan beberapa prototipe sebagian besar guru yang ada. Glickman (1981) mengemukakan bahwa seorang guru umumnya mempunyai dua kemampuan dasar, yaitu berpikir abstrak dan tingkat komitmen dari para guru, hal itu dipakai oleh Glickman untuk model menganalisis kategori guru, yaitu:

\section{Tingkat Berpikir Abstrak}

Setiap guru punya kompeten, yaitu tingkat berpikir abstrak kreatif dan imajinatif. Beberapa penelitian telah membuktikan bahwa riset yang dilakukan oleh Harvey (1966), Hunt dan Joyce (1967) menunjukkan bahwa guru yang tingkat perkembangan kognitifnya tinggi akan berpikir lebih abstrak imajinatif, kreatif dan demokratis. Mereka akan lebih fleksibel dalam melakukan tugasnya. Adapun pengertian berpikir abstrak dan imajinatif adalah kemampuan untuk memindahkan konsep, visualisasi, mengidentifikasi dan mengumpulkan data. Berikut ini matrik yang berisi tentang rincian berpikir abstrak, yaitu :

Tabel 15.1 : Tingkat Berpikir Abstrak

\begin{tabular}{|ll|ll|}
\hline \multicolumn{2}{|c|}{ Yang Rendah } & \multicolumn{2}{|c|}{ Yang Tinggi } \\
\hline 1. & $\begin{array}{l}\text { Bingung bila } \\
\text { menghadapi masalah }\end{array}$ & 1. & $\begin{array}{l}\text { Dalam menghadapi } \\
\text { masalah selalu dapat } \\
\text { mencari alternatif }\end{array}$ \\
2. & $\begin{array}{l}\text { Tidak mengetahui cara } \\
\text { bertindak bila } \\
\text { menghadapi masalah }\end{array}$ & 2. & $\begin{array}{l}\text { Dapat menggunakan } \\
\text { beberapa alternatif dalam } \\
\text { memecahkan masalah }\end{array}$ \\
3. & $\begin{array}{l}\text { Selalu berkata saya tidak } \\
\text { bisa, tolonglah saya }\end{array}$ & \\
& & \\
\hline
\end{tabular}


2. Tingkat Komitmen

Yang dimaksud dengan komitmen adalah kecenderungan dalam diri seseorang untuk merasa terlibat aktif dengan penuh rasa tanggungjawab, dan dalam komitmen tercakup usaha dan dorongan serta waktu yang cukup banyak. (Glickman, 1981). Komitmen dan kepedulian dapat timbul bila ada cinta terhadap tugas dan panggilan guru, walaupun pada saat masuk pendidikan guru masih merasa belum terpanggil, tapi keterpanggilan itu dapat dibina, dipupuk melalui proses pembentukan profesi.

Perilaku guru yang punya komitmen dapat digambarkan sebagai berikut :

\section{Tabel 15.2 : Tingkat Komitmen}

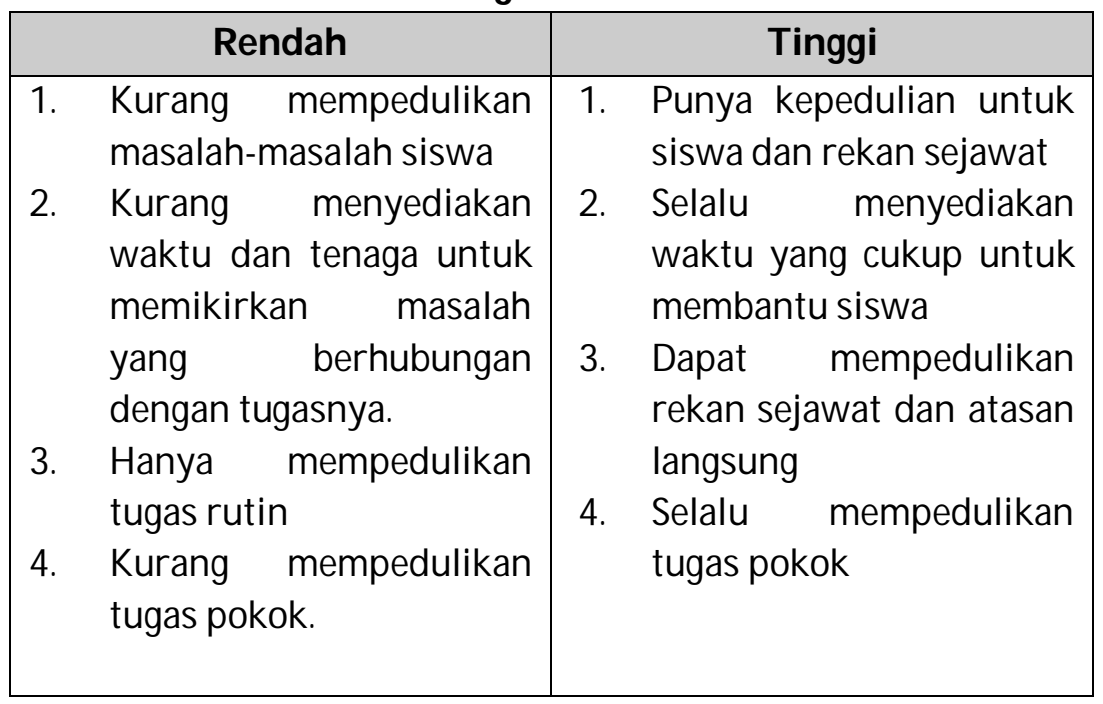

Prototipe guru berdasarkan kedua tingkat kemampuan dasar yang telah disebutkan di atas dapat digambarkan dan dikelompokkan seperti berikut ini : 


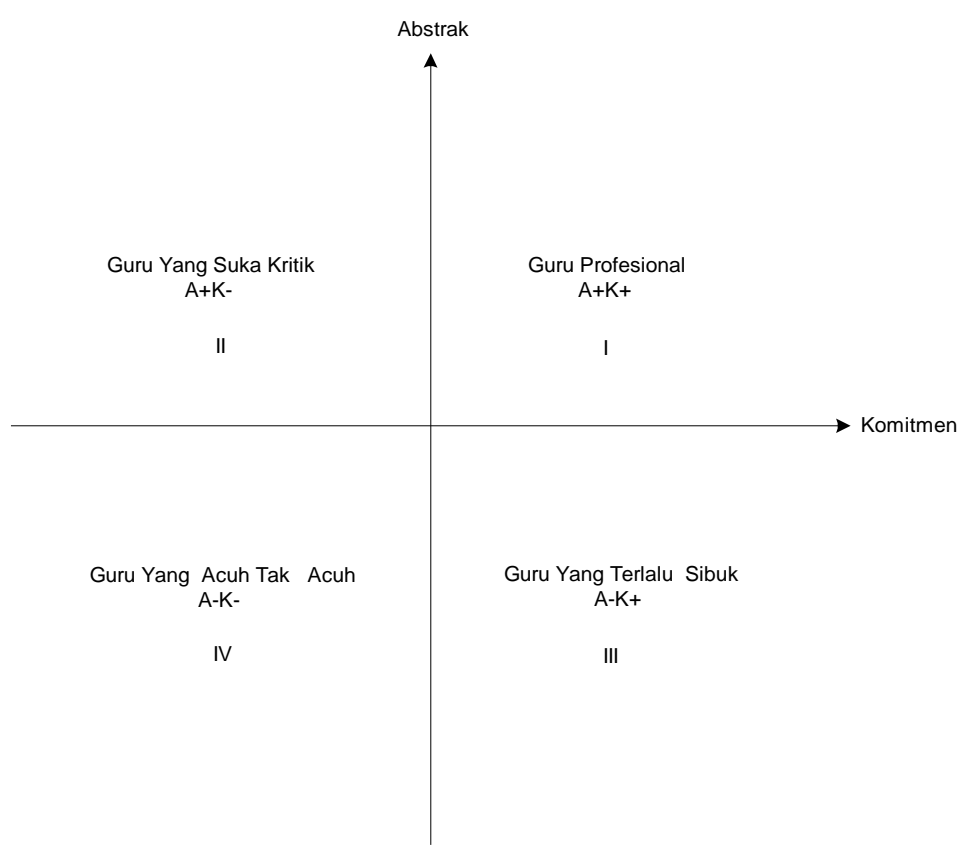

Gambar 15.1 : Prototipe guru

Dari Gambar 15.1 di atas ada empat (4) prototype guru, yakni:

1. Prototipe guru pada sisi I disebut guru profesional, $\mathrm{A}+\mathrm{K}+$

2. Prototipe guru pada sisi II disebut guru yang tukang kritik, $\mathrm{A}+\mathrm{K}-$

3. Prototipe guru pada sisi III disebut guru yang selalu sibuk, A$\mathrm{K}+$

4. Prototipe guru pada sisi IV disebut guru yang acuh tak acuh, A$\mathrm{K}-$

Kriteria tipe guru-guru di atas dapat dijelaskan sebagai berikut :

1. Guru yang profesional $(\mathrm{A}+\mathrm{K}+)$

Tingkat abstraknya tinggi (baca A+)

- Dalam menghadapi masalah selalu dapat mencari pemecahan alternatif.

- Dapat menggeneralisasi berbagai alternatif dalam berbagai masalah. 
Tingkat Komitmen tinggi (baca K+)

- Punya kepedulian untuk siswa dan rekan sejawat.

- Selalu menyediakan waktu dan tenaga yang cukup untuk membantu siswa.

- Dapat mempedulikan rekan sejawat dan atasan langsung

- Selalu mempedulikan tugas pokok.

2. Guru yang suka kritik (A+K-)

Tingkat abstraknya tinggi (baca A+)

- Dalam menghadapi masalah selalu dapat mencari pemecahan alternatif

- Dapat menganalisis berbagai alternatif dalam memecahkan masalah.

Tingkat komitmen rendah (baca K-)

- Kurang mempedulikan masalah-masalah siswa

- Kurang menyediakan waktu dan tenaga untuk memikirkan masalah yang berhubungan dengan tugasnya

- Hanya mempedulikan tugas-tugas rutin

- Kurang mempedulikan tugas-tugas pokok

3. Guru yang terlalu sibuk (A-K+)

Tingkat abstraknya rendah (baca A-)

- Bingung bila menghadapi masalah

- Tidak mengetahui cara bertindak yang tepat bila menghadapi masalah

- Selalu berkata saya tidak mampu, tolonglah saya Tingkat komitmen tinggi (baca $\mathrm{K}+$ )

- Punya kepedulian untuk siswa dan rekan sejawat

- Selalu menyediakan waktu dan tenaga yang cukup untuk membantu siswa

4. Guru yang acuh tak acuh (A-K-) 
Tingkat abstraknya rendah (baca A-)

- Bingung bila menghadapi masalah

- Tidak mengetahui cara bertindak bila menghadapi masalah

- Selalu berkata saya tidak bisa, tolonglah saya

Tingkat komitmen rendah (baca K-)

- Kurang mempedulikan masalah-masalah siswa

- Kurang menyediakan waktu dan tenaga untuk memikirkana masalah yang berhubungan dengan tugasnya.

- Hanya mempedulikan tugas rutin

- Kurang mempedulikan tugas pokok.

Demikianlah, pengetahuan tentang prototipe guru di atas akan membantu kita untuk merancang program pembinaan dan pengembangan profesi guru ke tingkat pencapaian tujuan yang profesional, sekaligus mengukur sampai di mana jenis tipe guru yang sekarang kita miliki.

\section{Kode Etik Pendidik}

Kode etik pendidik adalah salah satu bagian dari profesi pendidik. Artinya setiap pendidik yang professional akan melaksanakan etika jabatannya sebagai pendidik. Pidarta (1997) mengemukakan kode etik pendidik sebagai berikut:

5. Beriman dan bertakwa kepada Tuhan Yang Maha Esa.

6. Setia pada Pancasila, UUD 1945, dan negara.

7. Menjunjung tinggi harkat dan martabat peserta didik.

8. Berbakti kepada peserta didik dalam membantu mereka mengembangkan diri.

9. Bersikap ilmiah dan menjunjung tinggi pengetahuan, ilmu, teknologi, dan seni sebagai wahana dalam pengembangan peserta didik.

10. Lebih mengutamakan tugas pokok dan atau tugas negara lainnya daripada tugas sampingan.

11. Bertanggung jawab, jujur, berprestasi, dan akuntabel dalam bekerja. 
12. Dalam bekerja berpegang teguh kepada kebudayaan nasional dan ilmu pendidikan.

13. Menjadi teladan dalam berperilaku.

14. Berprakarsa.

15. Memiliki sifat kepemimpinan.

16. Menciptakan suasana belajar atau studi yang kondusif.

17. Memelihara keharmonisan pergaulan dan komunikasi serta bekerja sama dengan baik dalam pendidikan.

18. Mengadakan kerjasama dengan orang tua siswa dan tokohtokoh masyarakat.

19. Taat kepada peraturan perundang-undangan dan kedinasan.

20. Mengembangkan profesi secara kontinu.

21. Secara bersama-sama memelihara dan meningkatkan mutu organisasi profesi.

Kode etik pendidik dapat pula diambil dari pendapat Imam alGhazali (dalam Uhbiyati, 1998) yang menasihati para pendidik Islam agar memiliki kode etik sebagai berikut:

1. Kasih sayang terhadap murid-muridnya.

2. Tidak mengharapkan balas jasa ataupun ucapan terima kasih, tetapi mengajar untuk maksud mencari keridhaan Allah dan mendekatkan diri kepada-Nya.

3. Mencegah murid dari akhlak yang tidak baik.

4. Tidak menimbulkan rasa benci pada diri siswa terhadap suatu cabang ilmu yang lain.

5. Seorang guru harus mengamalkan ilmunya dan tidak berlainan kata dengan perbuatannya.

Abdurrahman An-Nahlawi (1989) menambahkan kode etik yang harus dimiliki pendidik, adalah:

1. Tingkah laku dan pola pikir guru bersifat rabbani.

2. Ikhlas, jujur, adil, dan sabar.

3. Senantiasa membekali diri dengan ilmu dan membiasakan untuk terus mengkajinya. 
4. Mampu mengelola siswa, tegas dalam bertindak serta meletakkan berbagai perkara secara proporsional.

5. Tanggap terhadap berbagai kondisi dan perkembangan dunia yang mempengaruhi jiwa, keyakinan dan pola berpikir angkatan muda.

Dari uraian di atas dapat diketahui bahwa ada sebagian butir kode etik sudah terlaksana, dan sebagian lain pelaksanaannya belum baik atau bahkan belum terlaksana sama sekali. Sebab itu perlu dipikirkan upaya mengatasi hambatan yang menyebabkan sejunlah butir kode etik pendidik tidak terlaksana dengan baik. Upaya peningkatan pelaksanaan kode etik pendidik tersebut, dalam garis besarnya dapat dilakukan sebagai berikut:

1. Para pendidik diberi kesempatan seluas-luasnya, selama mereka mampu, untuk studi lebih lanjut ke S1, S2, atau S3. Dengan menimba ilmu lebih banyak diharapkan dapat meningkatkan sikap dan pribadinya sebagai pendidik.

2. Membangun perpustakaan pendidik di lembaga-lembaga pendidikan yang belum memiliki perpustakaan. Perpustakaan ini dipersiapkan untuk pendidik yang tidak sempat studi lebih lanjut.

3. Meningkatkan kesejahteraan para pendidik. Hal ini dapat diatasi dengan memperhatikan system upah yang baik, yakni: Upah dapatlah memenuhi standar fisik minimum, upah harus adil, Upah harus meningkat, dan upah harus mengikat.

4. Sejalan dengan upaya meningkatkan kesejahteraan para pendidik, kerjasama lembaga pendidikan dengan orang tua dan tokoh-tokoh masyarakat perlu ditingkatkan.

5. Fungsi DP3 perlu dibenahi dan ditingkatkan.

6. Selain dengan DP3, pelaksanaan etika pendidik dapat juga ditingkatkan dengan mengintensifkan pengawasan.

7. Kalau para pendidik yang melanggar kode etik tidak mempan dinasihati atau dihimbau oleh pemimpin lembaga maka para pemimpin ini dapat mengenakan sanksi kepada mereka sesuai dengan aturan yang berlaku atau sesuai dengan peraturan lembaga bersangkutan yang sudah disepakati bersama. 


\section{Pengembangan Profesi Guru}

Ada beberapa cara dan tempat untuk mengembangkan profesi guru (pendidik), antara lain:

22. Dengan belajar sendiri di rumah (otodidak). Jalan ini bisa ditempuh dengan memiliki perpustakaan pribadi di rumah. Bukubuku hsrud dibaca dengan teratur tidak hanya dipakai pajangan untuk menunjukkan prestise sebagai sarjana, master ataupun doctor.

23. Belajar di perpustakaan khusus untuk pendidik atau di perpustakaan umum.

24. Dengan cara membentuk persatuan pendidik sebidang studi atau yang berspesialisasi sama dan melakukan tukar pikiran atau berdiskusi dalam kelompoknya masing-masing. Hal ini bisa dilakukan melalui Musyawarah Guru Mata Pelajaran (MGMP) atau Kelompok Kerja Guru (KKG), dan lain-lain.

25. Mengikuti pertemuan-pertemuan ilmiah di manapun pertemuan itu diadakan selama masih dapat dijangkau oleh pendidik. Pertemuan ilmiah itu misalnya, ceramah ilmiah, halaqoh-halaqoh, seminar, semiloka, diskusi ilmiah, simposium, pelatihan, dan lainlain.

26. Belajar secara formal di lembaga-lembaga pendidikan baik di dalam negeri maupun di luar negeri. Studi lanjut itu bias ditingkat S1, S2, atau S3. Aatau dapat juga dalam waktu pendek satu sampai enam bulan untuk mendalami bidang studi tertentu yang disahkan dengan pemberian sertifikat.

27. Mengikuti pertemuan-pertemuan organisasi profesi pendidikan.

28. Ikut mengambil bagian dalam kompetisi-kompetisi ilmiah. Seperti kompetisi untuk mendapatkan dana penelitian dari pemerintah pusat, kompetisi pengabdian masyarakat, kompetisi desain bangunan, kompetisi pemikiran inovatif, dan lain-lain.

Setelah mengetahui cara dan tempat pengembangan profesi, kemudian apa yang harus dikerjakan dalam mengembangkan profesi itu. Hal-hal yang patut dilakukan dalam mengembangkan profesi adalah (Pidarta, 1997): 
1. Membaca buku, jurnal, majalah, disket, compact disk (CD), terutama yang berkenaan dengan materi-materi baru yang ditekuni dan cara-cara mendidik baru.

2. Meringkas isi bacaan. Ringkasan ini bermanfaat untuk memudahkan mengingat sebab disusun atas pemahaman sendiri dengan sistematika sendiri pula. Di samping itu rinkasan ini menghindarkan pendidik untuk selalu membaca banyak, sebab sangat sulit mengingat sesuatu dengan satu kali baca.

3. Membuat makalah, yaitu mengemukakan ide baru yang didukung oleh informasi-informasi ilmiah. Manfaat membuat makalah adalah belajar menyusun pikiran secara teratur dalam bentuk tulisan serta belajar rajin mengumpulkan informasi dan memadukannya dengan ide baru sehingga menjadi tulisan yang enak dibaca dengan isi yang menarik.

4. Melakukan penelitian, baik penelitian perpustakaan (library research), laboratorium (laboratorium research), maupun penelitian lapangan (field research).

5. Membuat artikel hasil penelitian atau artikel pemikiran inovatif. Artikel ini adalah untuk konsumsi majalah atau jurnal ilmiah. Hasil penelitian yang baik adalah bila ia dikomunikasikan lewat artikel, agar dapat dimanfaatkan oleh banyak orang.

6. Menulis buku ilmiah baik untuk sekolah maupun perguruan tinggi. Penulisan buku ini perlu digalakkan sejak awal agar ilmu pengetahuan tumbuh di Indonesia.

7. Mengaplikasikan ilmu untuk kepentingan masyarakat umum atau mengadakan pengabdian kepada masyarakat.

\section{Kesimpulan}

'Guru' adalah suatu sebutan bagi jabatan, posisi dan profesi bagi seseorang yang mengabdikan dirinya dalam bidang pendidikan melalui interaksi edukatif secara terpola, formal, dan sistematis (Surya, 1998). Secara historis jabatan guru mengandung arti pelayanan yang luhur (noblest vocation). Mereka disebut dengan paedagogos atau pelayan anak, pelayan terhormat yang memanusiakan manusia, atau abdi manusia (gogos humaniora). Guru 
adalah salah satu komponen manusiawi dalam proses belajarmengajar, yang ikut berperan dalam usaha pembentukan sumber daya manusia yang potensial dalam pembangunan. Oleh karena itu, guru haruslah sosok yang dapat 'digugu' dan 'ditiru'. Guru harus berperan serta aktif dan menempatkan kedudukannya sebagai tenaga profesional, sesuai dengan tuntutan masyarakat yang semakin berkembang. 


\section{DAFTAR PUSTAKA}

Ahmadi, Abu dan Nur Uhbiyati. 2001. Ilmu Pendidikan. Jakarta: Rineka Cipta.

Al-Abrasyi, M. Athiyah. 1974. Dasar-dasar Hukum Pendidikan Islam. Terj. Bustami A. Ghani dan Johar Bahry. Jakarta: Bulan Bintang.

Anshari, H.M Hafi. 1982. Pengantar Ilmu Pendidikan. Jember: Media Press.

Arifin dan Aminuddin Rosyad. 1998. Dasar-dasar Kependidikan. Jakarta: Dirjen Bimbaga Islam Depag RI.

Arifin, M. 2003. Ilmu Perbandingan Pendidikan. Jakarta: Golden Terayon Press.

Barnadib, Imam Sutari. 1984. Pengantar Ilmu Pendidikan Sistematis. Yogyakarta: IKIP Yogyakarta.

Blazely, Lloyd D. et. al. 1997. Science Study. Jakarta: The Japan Grant Foundation.

Callahan, Joseph F. and Leonard H. Clark. 1983. Foundations od Education. New York: McMillan Publishing Co., Inc.

Coombs, P.M. 1970. The World Educational Crisis, a System Analysis. New York: Oxford University Press. (Elective A-4. Innotech, Manila, 1979)

Darajat, Zakiyah (et.al). 2004. Ilmu Pendidikan Islam. Jakarta: Bumi Aksara.

Departemen Agama RI. 2003. Memahami Paradigma Baru Pendidikan Nasional dalam Undang-Undang Sisdiknas. Jakarta: Depag RI. . 1992. Al Qur'an dan Terjemahnya. Semarang: PT. Tanjung Mas Inti.

Departemen Pendidikan Nasional. 2004. Pedoman Pembelajaran Tuntas. Jakarta: Dirjen Dikdasmen Depdiknas.

Djumhur dan Danasuparta. 1974. Sejarah Pendidikan. Bandung: CV. Ilmu.

Edgar Faure (et.al). 1972. Learning to be, The Word of Education Today and Tomorrow. Unesco: Harran London. 
Ekosusilo, Madyo. 1985. Dasar-dasar Pendidikan. Semarang: Effuar Publishing.

Elsbree, Willard S., H.J. McNally and R. Winn. 1959. Elementary School Administration and Supervision. New York: American Book Company.

Hadi, Soedama. 1983. Pendidikan Nasional dan Pengembangan Masyarakat. Yogyakarta: IKIP Sanata Dharma.

Hadiyanto. 2004. Mencari sososk Desentralisasi Manajemen Pendidikan di Indonesia. Jakarta: Rineka Cipta.

Hanison, Elmer. 1955. The Foundation of Modern Education. USA: Rinehart.

Idris, Zahara. 1987. Dasar-dasar Kependidikan I. Padang: Angkasa Raya. Ihsan, Fuad. 2003. Dasar-dasar Kependidikan. Jakarta: Rineka Cipta.

Immegart, Glenn L. and Francis J. Pilecki. 1972. In Introduction to Systems for The Educational Administrator. California: Addison Wesly Publishing Company.

Indrakusuma, Amir Daien. 1976. Pengantar Ilmu Pendidikan. Surabaya: Usaha Nasional.

Jamaludin. 2002. Pembelajaran yang Efektif: Faktor-faktor yang Mempengaruhi Prestasi Siswa. Jakarta: Depatemen Agama RI.

Kindret, L.W. 1957. School Public Relation. New York: Prentice Hal.

Kusrahayu, Ninuk. 2006. Hand Out Pengantar Ilmu Pendidikan. Universitas Wijaya Kusuma, Surabaya.

Lambert, L.T. 1998. Building Leadership Capacity in School. Virginia: ASCD.

Lester D. Crow \& Alice D. Crow. 1960. Introduction to Education. New York: American Book Company.

Lodge, Rupert C. 1947. Philosophy of Education. New York: Harper \& Brother.

Manan, Ibrahim. 1988. Dasar-dasar Sosial Budaya Pendidikan. Jakarta: Dep. Pendidikan dan Kebudayaan.

Marimba, Ahmad D. 1980. Pengantar Filsafat Pendidikan Islam. Bandung: Al-Ma'arif.

McAhsan, H.H. 1983. Comprehensive Planning For School Administrations. USA: Advocate Publishing Group. 
Mead, Margaret. 1955. Cultural Pattern and Technical Change. New York: Unesco.

Mulyasa, Enco. 2005. Menjadi Kepala Sekolah Profesional. Bandung: PT. Remaja Rosdakarya.

. 2006. Menjadi Guru Profesional. Bandung: PT. Remaja Rosdakarya.

. 2006. Kurikulum Tingkat Satuan Pendidikan. Bandung: PT. Remaja Rosdakarya.

Pidarta, Made. 1997. Landasan Kependidikan. Jakarta: Rineka Cipta.

Purwanto, M. Ngalim. 1995. Ilmu Pendidikan Teoretis dan Praktis.

Bandung: PT Remaja Rosda Karya.

.1996. Administrasi Pendidikan. Jakarta: Mutiara Sumber Widya. . 1985. Ilmu Pendidikan. Bandung: Remaja Karya.

Ririn Afidah. 2007. Dasar-dasar Ilmu Pendidikan. Tanpa Penerbit.

Sahertian, Piet A. 1994. Profil Pendidik Profesional. Yogjakarta: Andi Offset.

Saleh, Abdurrahman. 1980. Didaktik Pendidikan Agama. Jakarta: Bulan Bintang.

Samani, Muchlas. 2000. Kecakapan Hidup: Melalui Pendekatan Berbasis Luas. Surabaya: Swa Bina Qualita UNESA.

Sardiman, AM. 2006. Interaksi dan Motivasi Belajar Mengajar. Jakarta: PT Raja Grafindo Persada.

Soetopo, Hendyat dan Wasty Soemanto. 1080. Pengantar Operasional Administrasi Pendidikan. Surabaya: Usaha Nasional.

Sujanto, Agus. 1980. Psikologi Perkembangan. Jakarta: Aksara Baru.

Surya, M. 1998. Bimbingan dan Konseling. Jakarta: Depdikbud.

Suryosubroto, B. 1983. Beberapa Aspek Dasar-dasar Kependidikan. Jakarta: PT Bina Aksara.

Syam, Noor (et.al). 1987. Pengantar Dasar-dasar Kependidikan. Surabaya: Usaha Nasional.

Tim Dosen FKIP UNS. 1984. Dasar-dasar Pendidikan. Surakarta: Universitas Sebelas Maret.

Tim Dosen IKIP Surabaya. 1992. Ilmu Pendidikan . Surabaya: IKIP Surabaya. 
Tim Dosen IKIP Surabaya. 1996. Pengantar Pendidikan Bagian I. Surabaya: Unesa University Press.

Uhbiyati, Nur. 1997. Ilmu Pendidikan Islam I dan II. Bandung: Pustaka Setia.

Undang-Undang Dasar Republik Indonesia 1945 dan Amandemen. 2006. Surabaya: Karya Utama.

Vaizey, John. 1974. Pendidikan di Dunia Modern. Jakarta: Gunung Agung.

Yunus, Mahmud. 1995. Sejarah Pendidikan Islam di Indonesia. Jakarta: Mutiara Sumber Widya.

Zanti Arbi, Sutan. 1988. Pengantar Kepada Filsafat Pendidikan. Jakarta: Dep. P \& K Ditjen PT P2LPTK.

Zuhairini (et.al). 1981. Metodik Khusus Pendidikan Islam. Malang: Biro Ilmiah IAIN Sunan Ampel. 
Amru Almu'tasim - Menyoal Profesionalisme Guru Profesional: Sebuah Telaah Kritis 